\title{
Cavity-dwelling suspension feeders in coral reefs- a new link in reef trophodynamics
}

\author{
Claudio Richter*, Mark Wunsch \\ Zentrum für Marine Tropenökologie, Fahrenheitstr. 1, 28359 Bremen, Germany
}

\begin{abstract}
The small-scale distributions of chlorophyll a (chl a), pheopigments, oxygen and currents were determined in horizontal sections between coral reef cavities and benthic boundary layer waters $(\mathrm{BBL})$ to estimate rates of grazing and respiration by cryptic cavity-dwelling (coelobite) suspension feeders. We investigated 0.5 to $5 \mathrm{~m}$ long and 0.1 to $1 \mathrm{~m}$ wide cavities in fringing reefs on the western coast of the Gulf of Aqaba (Red Sea), between 2 and $16 \mathrm{~m}$ depth. Within cavities net currents averaged $0.9 \mathrm{~cm} \mathrm{~s}^{-1}$, or $22 \%$ of the current speed measured in BBL $\sim 2 \mathrm{~m}$ away from the reef. In spite of rapid flushing of cavity waters within a few minutes, we encountered significant chl $a$ and oxygen depletions relative to $\mathrm{BBL}$, particularly under oligotrophic conditions. Chl a depletions amounted, on average, to $0.10 \pm 0.03 \mathrm{mg} \mathrm{m}^{-3}$ (median \pm median absolute deviation [MAD]) or $54 \%$ (max. $86 \%$ ) of BBL values and showed a positive relation to coelobite suspension feeder densities. Pheopigments, by contrast, remained remarkably constant, indicating selective grazing of the mainly picoplankton-sized food. Oxygen depletions were weak and mainly related to flushing. In sack-shaped cavities they amounted to $13.6 \pm 6.1 \mathrm{mmol} \mathrm{m}^{-3}$ or 3 to $9 \%$ of BBL concentrations. Analyses of water flow and chl a distributions show that under oligotrophic summer conditions $0.7 \mathrm{~g} \mathrm{C} \mathrm{m}^{-2} \mathrm{~d}^{-t}$ of phytoplankton disappears within the upper $1 \mathrm{~m}$ of cavernous reef framework. This conservative estimate is about 1 order of magnitude higher than grazing rates of coral-dominated communities on the exposed reef, rendering cryptofauna suspension feeding an important and new pathway of extrinsic organic matter into coral reefs.
\end{abstract}

KEY WORDS: Cavities · Crevices - Cryptofauna - Coelobites · Phytoplankton - Grazing - Respiration · Coral reefs

\section{INTRODUCTION}

Coral reef cavities are believed to constitute between 30 and $75 \%$ of the bulk volume of the coral reef (Garrett et al. 1971, Ginsburg 1983, Kobluk \& van Soest 1989) and between 60 and $75 \%$ of the total available surface (Jackson et al. 1971, Buss \& Jackson 1979, Logan et al. 1984), yet hardly anything is known about the ecology of this cryptic habitat. Logistic constraints have until now restricted research mainly to wide caves and caverns, on the one hand, and to the easily accessible cryptofauna communities under living corals and coral rubble, on the other. Only recently with the advent of video-endoscopic techniques has it become possible to investigate the wide-spread small crevices

\footnotetext{
·E-mail: crichter@uni-bremen.de
}

and galleries interlacing the reef framework (Wunsch \& Richter 1998).

Framework cavities result from the interaction of growth and erosion of the reef matrix, giving rise to an intricate irregular system of voids (Ginsburg 1983), which may extend several meters into the substrate (Zankl \& Schroeder 1972). The cavity walls thus provide a very large living space for low-light adapted organisms or coelobites (Ginsburg \& Schroeder 1973) and, hence, a potentially important interface for biogeochemical fluxes between the interior and exterior of the coral reef. Transport of nutrients and organic matter is driven by hydraulic exchange of water through crevices (Wolanski 1994) connecting with the benthic boundary layer waters (BBL) through numerous holes in the limestone (Fig. 1).

Due to the paucity of light, heterotrophs generally dominate coelobite communities, particularly cryptic suspension feeders such as sponges, ascidians or bryo- 


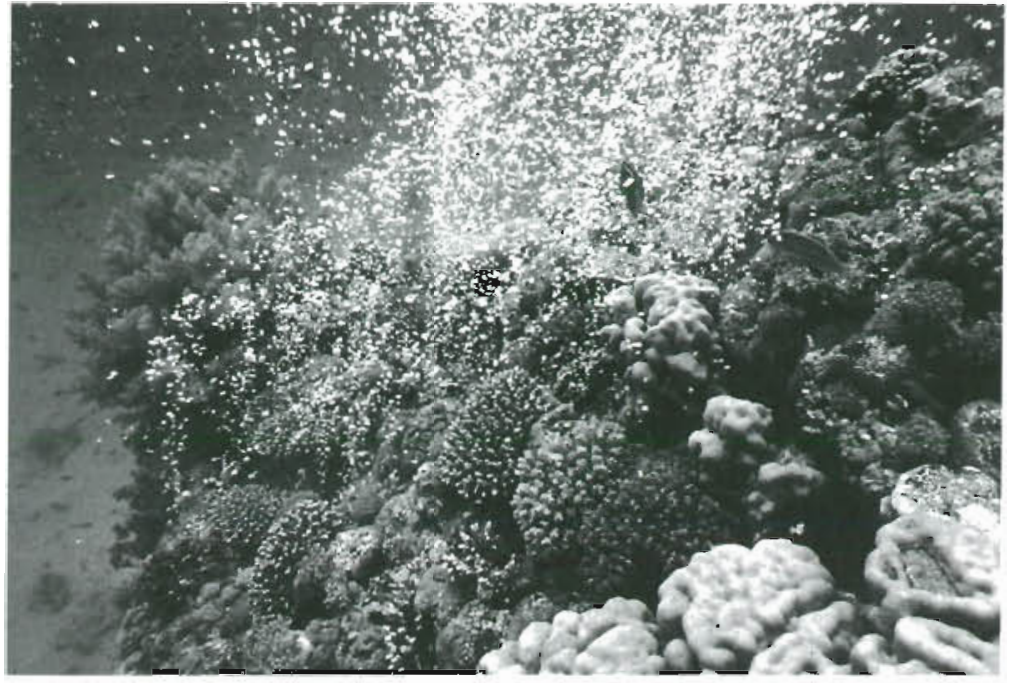

Fig. 1. Curtain of bubbles emerging from air trapped beneath a reef overhang and percolating through $2 \mathrm{~m}$ of cavernous reef (Moses Rock, Eilat, Israel)

phytes <1 $4 \mathrm{~m}$ predominate (Lindell \& Post 1995), albeit at very low total concentrations (usually $<0.3 \mathrm{mg}$ chlorophyll a (chl a) $\mathrm{m}^{-3}$. Genin et al, 1995)

Our main objective was to see if and to what extent the cryptofauna community is able to tap this dilute suspension of minute particulate food and to assess the magnitude of this potential pathway of extrinsic food into the coral reef. The specific objectives were (1) to determine the fluxes of chl a and pheopigments between reef cavities and BBL as proxies for picoplankton removal and digestion by the suspension-feeding community and (2) to compare the carbon input channeled through the suspension feeders with the oxygen uptake of the total cryptic community.

\section{MATERIAL AND METHODS}

zoans (Vasseur 1974, 1977, Logan et al. 1984). These groups may reach high biomass levels, comparable to that found on the reef's external surface (Hutchings 1974, Meesters et al. 1991), and cover almost the entire available substratum (Jackson et al. 1971) leaving at the most 1 to $5 \%$ unoccupied space (Buss \& Jackson 1979). Consequently, competition for space and food is intense (Buss 1979, Buss \& Jackson 1979).

Earlier investigations showed substantial depletions of nanoflagellates and bacteria in reef-fouling communities (Buss \& Jackson 1981), as well as growth responses of the filtering community to variations in flow conditions (Winston 1976, Wilkinson \& Vacelet 1979, Buss \& Jackson 1981). Recently, Gast et al. (1998) found significant reductions in bacterial numbers as well as enhanced bacterial growth in small coral reef crevices of Curaçao, and pointed at the possible role of cryptic sponges in filtering and remineralizing the picoplankton (<2 $\mu \mathrm{m}$ ) food (Gast et al. 1998). But no attempt has yet been made to quantify the uptake of plankton by the coelobite community.

In oligotrophic waters, most of the plankton in the smallest size classes consists of phytoplankton, mainly of cyanobacteria and prochlorophytes, which constitute more than $50 \%$ of the total plankton biomass (Ducklow 1990, Roman et al. 1990, Lindell \& Post 1995). For coral reefs, phytoplankton is mainly an extrinsic source of food, particularly on the narrow continental shelves of the Gulf of Aqaba, where steep slopes lead to a constant flushing of the fringing reefs with oceanic waters (Fig. 2, Reiss \& Hottinger 1984). In this semi-enclosed sea, the bulk of the phytoplankton biomass is picoplanktonic ( $>90 \%$ at all times, A. F. Post pers. comm.), particularly in summer when prochloro-
Site description. A total of 22 cavity transects were sampled at 4 fringing reef locations on the Egyptian and Israeli coast of the Gulf of Aqaba, a northeastern extension of the Red Sea (Table 1, Fig 2). Detailed descriptions of the sites and the biological and physical characteristics of the study area are found in Reiss \& Hottinger (1984), Yahel et al. (1998) and references therein. They represent typical flourishing reef sections of the western Gulf characterized by a narrow shelf, moderate slopes and a fairly open unconsolidated framework with little sediment infilling (Barnes \& Lazar 1993). Coastal currents are generally longshore and weak $\left(<20 \mathrm{~cm} \mathrm{~s}^{-1}\right)$, with semi-diurnal flow reversals during summer (Yahel et al 1998). A weak $\left(<2 \mathrm{~cm} \mathrm{~s}^{-1}\right)$ cross-shore circulation transports offshore water and plankton to the coast in the upper 10 to $20 \mathrm{~m}$, with subsequent downwelling and offshore flow near the bottom (Yahel et al. 1998). This cross-shore circulation onto the narrow shelf leads to a continuous, albeit weak, flushing of the reef slope with offshore waters.

At all sites we found the reef riddled with holes of various sizes connecting the framework cavities with the reef exterior (Fig. 1). Observations with an endoscopic videocamera ('CaveCam', Wunsch \& Richter 1998) support previous estimates that at least $30 \%$ of the volume of the upper reef framework is made up of cavities harbouring cryptic coelobite communities (Gischler \& Ginsburg 1996). Most cavities examined were densely covered with coelobites including many suspension feeding forms, such as encrusting sponges, ascidians and bryozoans (Wunsch \& Richter 1998, 


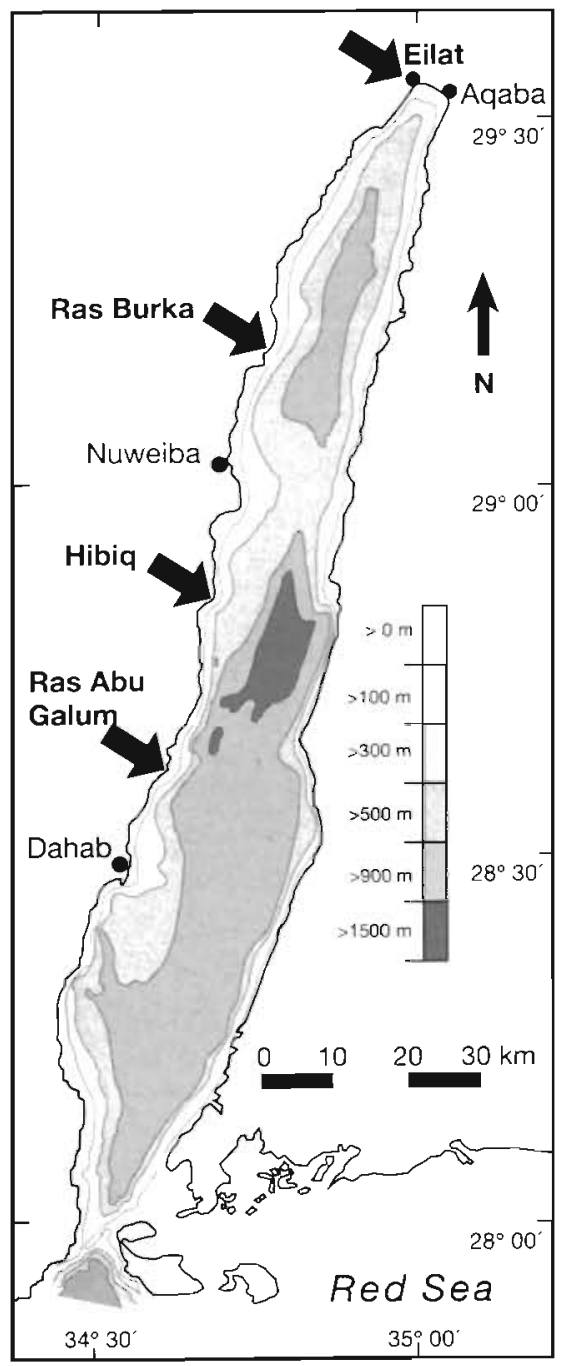

Fig. 2. Fringing reef locations (arrows) studied in the Gulf of Aqaba, Red Sea

Wunsch unpubl.). Coralline algae predominated near the cavity entrances.

Sampling and sample processing. Sampling was carried out in summer, when phytoplankton concentrations are at their annual minimum (Genin et al. 1995, Lindell \& Post 1995), and hence, most likely to be limiting to cryptic suspension feeders.

Different cavities were selected on exploratory SCUBA dives between 2 and $16 \mathrm{~m}$ depth. They primarily consisted of crevices and galleries in the framework of the reef slope, pinnacles and reef patches, but also of voids under coral overhangs and within coral thickets. Cavities were typically 0.1 to $1 \mathrm{~m}$ wide and extended 0.5 to $5 \mathrm{~m}$ horizontally or obliquely into the framework (Table 1). Dye

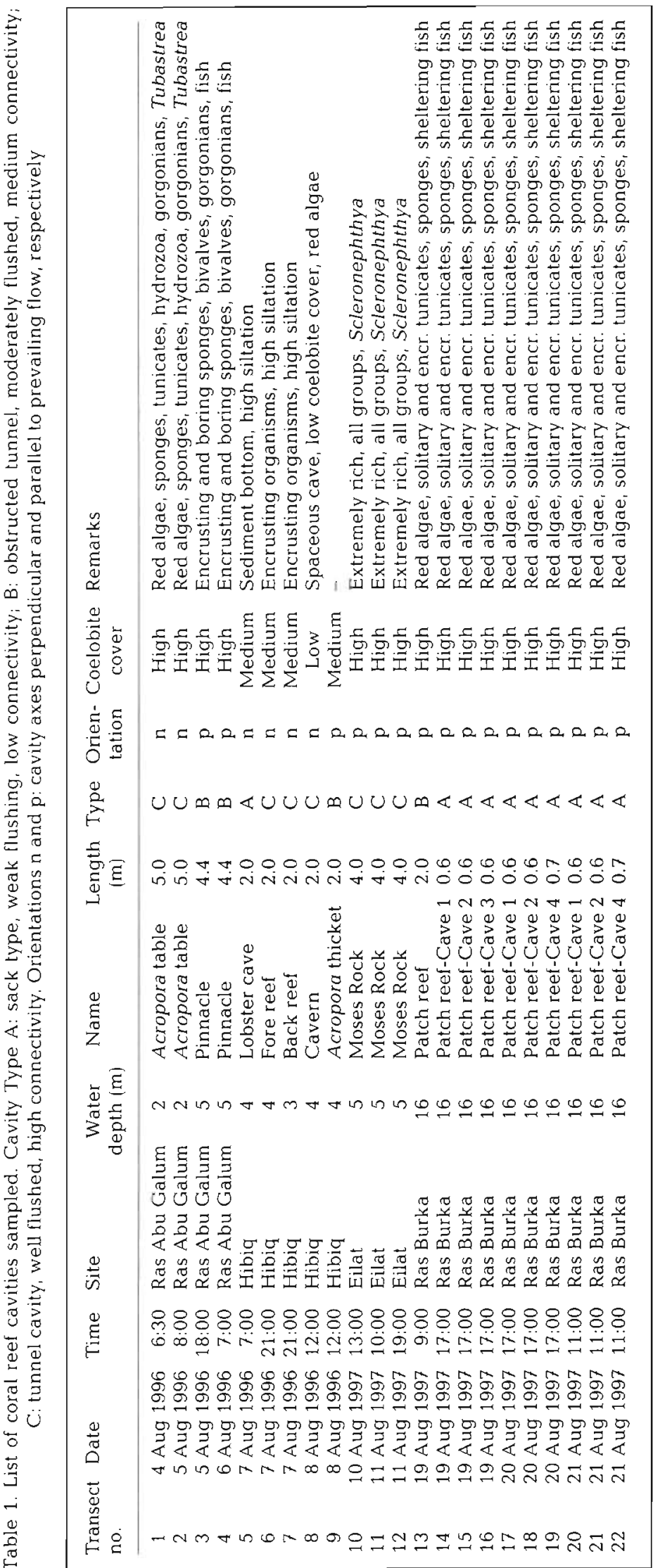


and air experiments revealed numerous secondary vertical connections between cavities and BBL (Fig 1). Based on their degree of connectivity with BBL we broadly classified the voids into 'low' connectivity sack-shape cavities with little water exchange through small cracks and fissures, 'medium' connectivity obstructed tunnel cavities with moderate exchange of water through a cavernous framework, and 'high' connectivity tunnel cavities with free water exchange between opposite openings (Table 1).

Cavities were inspected using the CaveCam fitted with a $3.5 \mathrm{~mm}$ super-wide angle lens (cf. Wunsch \& Richter 1998 for details). A preliminary assessment of cryptofauna densities was undertaken on site, identifying cavities with 'high', 'moderate' and 'low' densities of coelobite suspension feeders, corresponding to an estimated $<10 \%, 10$ to $30 \%$ and $>30 \%$ cover. A detailed quantitative analysis of coelobite communities in the Gulf of Aqaba is in progress and will be given elsewhere (Wunsch unpubl.). Cavities were marked with numbered buoys for later re-identification.

On subsequent dives, we sampled the small-scale distribution of phytoplankton pigments and oxygen between cavities and BBL. To this effect we carried out horizontal transects along the main axes of the cavities, and along (pinnacle and patch reef transects) or perpendicular (fore-reef transects) to the prevailing current direction. Pressure gradients due to vertical flow speed differences (cf. Vogel 1994) between the deeper main and the shallower secondary cavity openings resulted in weak net currents directed into the cavities. Thus, in general, water sampled at the distal end of a given cavity had passed over an assemblage of suspension feeders before reaching the sampling point. This sampling scheme is similar to the classical Eulerian design used in earlier plankton depletion studies over reef flats (Glynn 1973, Ayukai 1995), but different from the one used by Yahel et al. (1998), who studied inter alia the phytoplankton distribution over the reef normal to the prevailing flow.

Each transect was aligned with the center axis of the cavity. It was composed of a first sampling point in the outer bottom boundary layer (sensu Shashar et al. 1996) 1 to $2 \mathrm{~m}$ off the reef, outside the direct influence of corals. A second sampling point was centered in the cavity entrance and a variable number of further sampling points spaced evenly over the length of the cavity (Table 2). In addition, we collected water from the downstream ends of tunnel cavities and from the leeward sides of pinnacles.

On every sampling point we took triplicate water samples for both, phytoplankton pigments and oxygen, yielding a total of 18 to 42 samples per transect. Water was collected with $100 \mathrm{ml}$ polyethylene syringes fitted with $100 \mu \mathrm{m}$ screened silicone tubing mounted on a rod. The system was rinsed between samplings to

Table 2. Mean concentrations and standard deviations (SD) of phytoplankton pigment and oxygen concentrations and current speeds in bottom boundary layer (BBL) and cavity (Cav.) waters. k gives the number of sampling points on every transect. Significant gradients, according to the Page-test are denoted with asterisks ( $p<0.05, \cdots p<0.01$, ns: not significant). Positive current values are directed into the cavities

\begin{tabular}{|c|c|c|c|c|c|c|c|c|c|c|c|c|c|c|c|c|c|c|c|c|}
\hline \multirow{2}{*}{\multicolumn{2}{|c|}{$\begin{array}{l}\text { Transect } \\
\text { No. } k\end{array}$}} & \multicolumn{5}{|c|}{ Chlorophyll a (ng $\left.~^{-1}\right)$} & \multicolumn{5}{|c|}{ Pheopigments (ng $\mathrm{l}^{-1}$ ) } & \multicolumn{5}{|c|}{ Oxygen $\left(\mu \mathrm{mol} \mathrm{l}^{-1}\right)$} & \multicolumn{4}{|c|}{ Currents $\left(\mathrm{cm} \mathrm{s}^{-1}\right)$} \\
\hline & & BBL & $\mathrm{SD}$ & Cav. & $\mathrm{SD}$ & $\mathrm{p}$ & BBL & $\mathrm{SD}$ & Cav. & SD & $\mathrm{p}$ & $\mathrm{BBL}$ & $\mathrm{SD}$ & Cav. & $\mathrm{SD}$ & $\mathrm{p}$ & $\mathrm{BBL}$ & $\mathrm{SD}$ & Cav. & $\mathrm{SD}$ \\
\hline 1 & 5 & 99 & 14 & 51 & 18 & $\cdot$ & 65 & 10 & 66 & 5 & ns & 220.5 & 0.6 & 216.7 & 6.4 & ns & & & & \\
\hline 2 & 7 & 151 & 7 & 82 & 20 & $\cdots$ & 88 & 10 & 72 & 16 & ns & 214.0 & 7.6 & 203.9 & 1.2 & $\cdot$ & & & & \\
\hline 3 & 6 & 162 & 14 & 115 & 37 & $\cdots$ & 56 & 17 & 48 & 12 & $\cdot$ & 211.4 & 1.1 & 207.3 & 1.3 & $\cdot \cdot$ & & & & \\
\hline 4 & 6 & 188 & 16 & 96 & 45 & $\cdot \cdot$ & 45 & 6 & 50 & 27 & ns & 207.8 & 3.9 & 206.4 & 3.9 & $\cdot$ & & & & \\
\hline 5 & 4 & 170 & 3 & 165 & 24 & ns & 81 & 4 & 97 & 7 & $\cdot$ & 190.8 & 0.8 & 187.5 & 3.5 & ns & & & & \\
\hline 6 & 4 & 120 & 8 & 79 & 9 & . & 71 & 10 & 102 & 30 & $\cdot$ & 204.1 & 1.6 & 200.8 & 2.8 & $\cdot$ & & & & \\
\hline 7 & 3 & 97 & 7 & 79 & 17 & ns & 92 & 9 & 104 & 64 & ns & 194.4 & 7.0 & 198.8 & 2.3 & $\because$ & & & & \\
\hline 8 & 4 & 158 & 2 & 169 & 14 & $\mathrm{~ns}$ & 67 & 3 & 69 & 4 & ns & 209.1 & 2.5 & 210.0 & 1.2 & ns & & & & \\
\hline 9 & 4 & 156 & 5 & 112 & 22 & $\cdot \cdot$ & 74 & 4 & 87 & 10 & ns & 211.3 & 0.5 & 207.2 & 2.7 & $\cdots$ & & & & \\
\hline 10 & 7 & 1732 & 173 & 1.708 & 166 & ns & 296 & 52 & 349 & 67 & ns & 226.8 & 0.6 & 218.1 & 7.6 & .. & 2.7 & 1.2 & 1.2 & 0.9 \\
\hline 11 & 7 & 269 & 25 & 258 & 14 & ns & 74 & 16 & 70 & 5 & ns & 206.5 & 1.1 & 204.9 & 1.1 & $\cdots$ & 8.9 & 1.2 & 6.7 & 1.1 \\
\hline 12 & 7 & 1237 & 84 & 982 & 213 & $\cdot \cdot$ & 384 & 37 & 314 & 44 & . & 215.0 & 3.0 & 211.3 & 2.5 & .. & 2.6 & 0.5 & 1.4 & 0.7 \\
\hline 13 & 5 & 249 & 4 & 140 & 77 & $\because$ & 123 & 10 & 88 & 28 & ns & 207.8 & 2.2 & 206.6 & 2.8 & ns & 8.9 & 2.3 & 1.6 & 2.0 \\
\hline 14 & 3 & 184 & 6 & 67 & 7 & 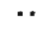 & 94 & 3 & 72 & 4 & ns & 215.8 & 2.2 & 202.6 & 1.9 & $\cdots$ & 3.4 & 0.2 & 1.0 & 0.3 \\
\hline 15 & 3 & 128 & 24 & 68 & 13 & $\because$ & 100 & 7 & 77 & 5 & ns & 208.8 & 0.4 & 197.4 & 4.0 & ns & 3.4 & 0.2 & 0.4 & 0.2 \\
\hline 16 & 3 & 191 & 21 & 42 & 6 & $\cdot \cdot$ & 106 & 6 & 97 & 3 & $\cdot$ & 201.8 & 0.7 & 195.9 & 0.3 & $\mathrm{~ns}$ & 3.4 & 0.2 & 02 & 0.2 \\
\hline 17 & 3 & 207 & 10 & 44 & 5 & $\because$ & 82 & 7 & 80 & 9 & ns & 220.1 & 4.7 & 201.6 & 0.5 & ns & 4.6 & 0.9 & 0.2 & 0.6 \\
\hline 18 & 3 & 118 & 26 & 103 & 10 & $\because$ & 105 & 10 & 87 & 4 & ns & 206.6 & 4.3 & 209.1 & 1.6 & $\mathrm{~ns}$ & 4.6 & 0.9 & 0.8 & 0.7 \\
\hline 19 & 3 & 210 & 20 & 49 & 18 & ns & 105 & 17 & 109 & 6 & ns & 203.1 & 2.5 & 202.0 & 3.5 & $\cdot$ & 106 & 0.8 & 1.1 & 0.2 \\
\hline 20 & 3 & 211 & 45 & 91 & 26 & $\cdot$ & 99 & 18 & 81 & 1.3 & ns & 214.0 & 0.9 & 205.5 & 0.5 & ns & 4.0 & 0.6 & 1.1 & 0.4 \\
\hline 21 & 3 & 109 & 6 & 86 & 7 & .. & 118 & 34 & 90 & 11 & ns & 207.4 & 0.6 & 211.6 & 6.0 & ns & 4.0 & 0.6 & 1.5 & 0.6 \\
\hline 22 & 3 & 209 & 2 & 67 & 13 & $\cdot$ & 83 & 12 & 82 & 11 & ns & 182.1 & 3.2 & 188.3 & 1.6 & $n s$ & 6.3 & 1.1 & 3.2 & 0.9 \\
\hline
\end{tabular}


avoid contamination from previous samples. Syringes were stored in a shaded box, transferred into the laboratory immediately after every dive and kept at ambient temperature until processing within $2 \mathrm{~h}$ of collection. The impermeability of the syringe pistons was tested fluorometrically, using distilled water drawn into syringes submerged in a bucket of fluorescein dye. The impermeability of the sampling system for oxygen was confirmed using seawater scrubbed with nitrogen measured immediately and $3 \mathrm{~h}$ after collection. No differences in chl $a$ and pheopigment concentrations were detected in syringes processed immediately and $3 \mathrm{~h}$ after collection.

$\mathrm{Chl} a$ and pheopigments were measured with a fluorometer (Turner Designs Mod. AU-10) using the acidification method (Parsons et al. 1984) after filtering $100 \mathrm{ml}$ of the sample on $25 \mathrm{~mm}$ diameter Whatman $\mathrm{GF} / \mathrm{F}$ filter and extracting the pigments in $90 \%$ acetone over a $24 \mathrm{~h}$ period at $4^{\circ} \mathrm{C}$ in the dark. Oxygen was measured by Winkler titration (Grasshoff et al. 1976).

Current speed data are available for the 1997 investigations only. The net displacement of suspended particles in the water was recorded simultaneously by video in BBL and inside the cavities. The BBL camera (a digital SONY VX1000E in a Seacam housing) was mounted on a tripod $-2 \mathrm{~m}$ upstream of the cavity entrances and oriented perpendicular to the current direction. The CaveCam was fitted with a small mirror at $45^{\circ}$ angle in front of the lens to record currents inside the narrow cavities (Wunsch \& Richter 1998). Both cameras used ambient light in conjunction with a narrow depth of field to trace the trajectories of advected particles against a dark background. For both the BBL camera and CaveCam, the focal plane was 10 to $30 \mathrm{~cm}$ away from the lens, far enough for the camera body not to affect the streamlines. CaveCam recordings were performed after syringe samplings to rule out the possibility of affecting the pigment and oxygen samples. BBL currents, which were recorded continuously on every dive, remained stable during the $-1 \mathrm{~h}$ sampling periods. We processed the video tapes by counting the number of frames it took a particle to cross the known distance between the left and right margins of the monitor screen. The current speed $\left(\mathrm{cm} \mathrm{s}^{-1}\right)$ was calculated by dividing the recording frequency ( 25 frames $\mathrm{s}^{-1}$ ) by the number of frames per unit length (frames $\mathrm{cm}^{-1}$ ).

These direct observations were complemented with water flushing experiments using fluorescent dye. We injected fluorescein homogenously into the given cavity and recorded the dilution of the fluorescence signal over time in $100 \mathrm{ml}$ syringe samples taken in given time intervals (seconds to minutes) in its center. Raw blank-corrected fluorescence was measured on a TD700 fluorometer equipped with a fluorescein filter kit
(486 nm excitation, 510 to $700 \mathrm{~nm}$ emission). At Moses Rock, a $4 \mathrm{~m}$ diameter pinnacle in the Coral Reserve of Eilat, Israel, the dilution of the dye was observed at 4 sampling points spanning the full length of a tunnel cavity facing into the current. Fluorescein is a nontoxic and conservative tracer with negligible adsorption properties (Turner Associates 1971). Yet, fluorescein experiments were always carried out last to rule out the possibility of interference with the phytoplankton pigment measurements.

Statistical analysis. Data were analyzed using standard statistical tests (Sachs 1992 and references therein).

To test for spatial gradients in the pigment and oxygen concentrations of the individual transects we ran the Page-test for $N=22$ transects with $k=3$ to 7 sampling points and $n=3$ replicates each. This nonparametric test for ordered alternatives is based on Friedman rank sums and tests for monotonously increasing (or decreasing) treatment effects (here: coelobite grazing and respiration) against the nullhypothesis of no treatment effects on the distributions of chl $a$, pheopigments and oxygen. The distal sections of tunnel and pinnacie transects (cavity exits, leeward sides of pinnacles) were excluded from analysis, because vagarious mixing with BBL would obliterate the test results.

In a second step we grouped the data into $k=4$ transect sections and examined the distributions of pigments and oxygen between BBL, cavity entrance, cavity and cavity exit by means of box-plots. Skewed distributions led us to report median and median absolute deviations (MAD) and to transform the data for subsequent analyses.

ANOVA was carried out to determine the effects of sampling sites, flushing, suspension feeder cover, etc. on the distributions of chl $a$ and oxygen in BBL and cavities. Raw data were log-normalized, percentages were arcsine-transformed. Scheffé's $F$ procedure was used for a posteriori multiple comparison of means.

To explore the effects of water renewal and phytoplankton availability on the amount of phytoplankton grazed in the cavities, we carried out a multiple linear regression analysis with the average current speed in the cavity and chl a concentration in BBL as independent variables and the percent concentration difference of chl a between BBL and cavity as a dependent variable.

\section{RESULTS}

In all but 1 of the 22 transects carried out, chl a concentrations were lower in coral reef cavities than in $\mathrm{BBL}_{i}$ in 16 transects examined the observed depletions 
were significant according to the Page-test $(\mathrm{p}<0.05$, Table 2). In contrast to the chl a, no clear pattern emerged for the pheopigments; higher and lower cavity concentrations compared to ambient values were found in roughly the same number of cases, and the few significant gradients featured opposite signs (Table 2). Oxygen values were lower in the cavities than in BBL in 17 out of 22 transects examined, and significantly so in 10 -as opposed to only 1 significant positive gradient ( $\mathrm{p}<0.05$, Table 2 ).

Transects 3 and 4 are given as examples for typical upstream-downstream distributions of chl a. pheopigments and oxygen between BBL and a cavernous forereef pinnacle in Ras Abu Galum, visited twice under strong $\left(\sim 20 \mathrm{~cm} \mathrm{~s}^{-1}\right.$ in BBL) and weak $\left(\sim 3 \mathrm{~cm} \mathrm{~s}^{-1}\right)$ current conditions (Fig. $3 \mathrm{~A}, \mathrm{~B}$ ). On the day with a strong current, we tound a linear decrease of chl a concentrations along the $4.4 \mathrm{~m}$ section of the pinnacle down to one-third of the upstream values at its leeward end (Fig. 3A, shaded area, left to right). During weak currents, chl a values plummeted to minımum values

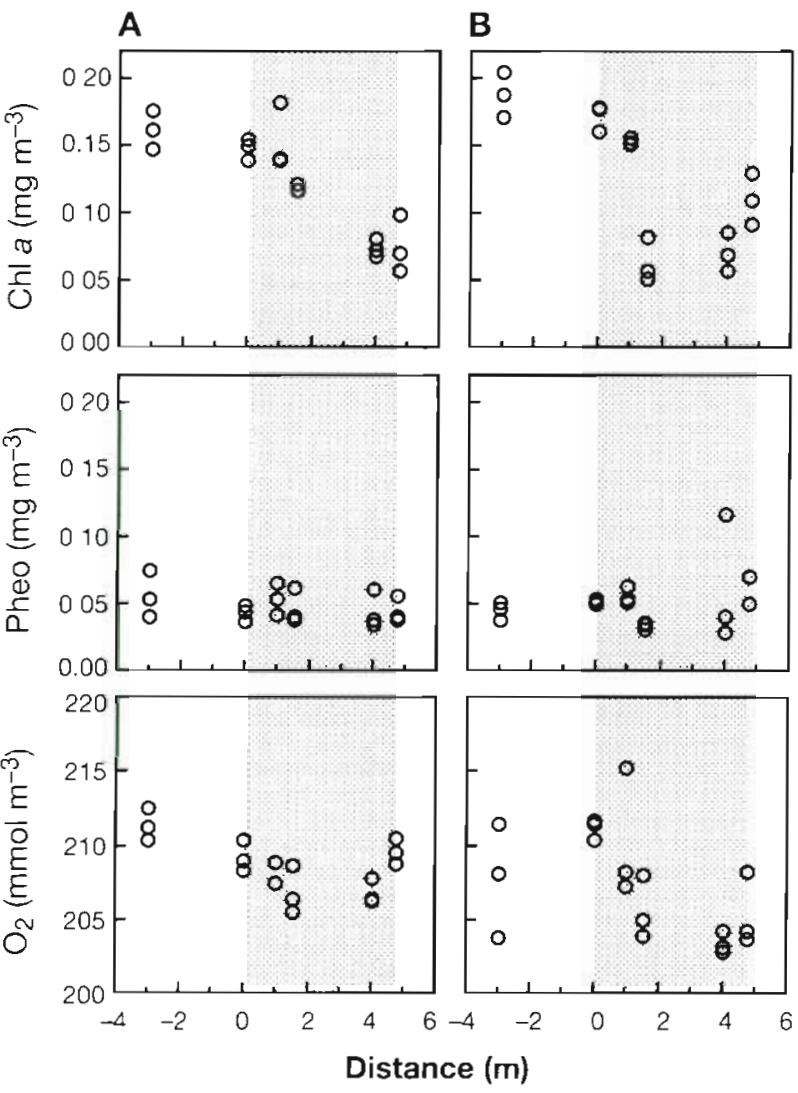

Fig 3 Cross-section through a fore-reef pinnacle in Ras Abu Galum. Egypt, with upstream (negative values on abscissa) and cavity (shaded area) concentrations of chlorophyll a (chl a), pheopigments and oxygen $\left(\mathrm{O}_{2}\right)$ durng $(\mathrm{A})$ strong $\left(-20 \mathrm{~cm} \mathrm{~s}^{-1}\right)$ and $(B)$ weak $\left(-3 \mathrm{~cm} \mathrm{~s}^{-1}\right)$ current conditions in the bottom boundary layer. $\mathrm{Chl} a$ and $\mathrm{O}_{2}$ gradients were signuficant according to the Page-test already in the upstream thurd of the transect and rose agaun towards the leeward end to about $50 \%$ of $\mathrm{BBL}$ concentrations (Fig. 3B). Pheopigments remained virtually unchanged along the first transect and displayed some inconsistent scatter on the second. Oxygen profiles showed weak but clear depressions in the inner reaches of the pinnacle of 4 and $7 \mathrm{mmol} \mathrm{m}^{-3}$, respectively. A maximum at the upstream entrance was apparent under weak current conditions only. It colnclded with a high cover of coralline algae.

$\mathrm{Chl}$ a concentrations were $<0.3 \mathrm{mg} \mathrm{m}^{-3}$ throughout the study ('normal summer' conditions. Fig. 4A, Table 2), with the exception of Transects 10 and 12 at Moses Rock, Eilat, where we encountered, between tides, a bloom with very high pigment concentrations in the BBL ranging between 1.1 and $2.0 \mathrm{mg} \mathrm{chl} \mathrm{a} \mathrm{m}^{-3}$ (Fig. 4B, Table 2).

The normal summer situation (Fig. 4A) was characterized by significant chl a differences along the 'average' transect (ANOVA, log-normalized data, $F_{3,225}=$ 22.43, $p<0.0001)$. The strongest depletion occurred between BBL and the cavity section $(-54 \%$, Scheffés $\mathrm{p}<$ $0.0001)$, with average (median \pm MAD) concentrations of $0.188 \pm 0.028$ and $0.086 \pm 0.030 \mathrm{mg} \mathrm{m}^{-3}$. respectuvely. No spatial differences were detectable for either pheopigments $\left(F_{3,225}=1.96, \mathrm{p}=0.12\right)$ or oxygen $\left(F_{3,201}=2.52\right.$, $\mathrm{p}=0.06$, Fig. 4A). Net flow inside the cavities averaged $0.89 \pm 0.27 \mathrm{~cm} \mathrm{~s}^{-1}$ or $216 \%$ of the current speed measured in BBL (Fig. 4A). This corresponds to a mean water passage time of less than 4 min (225 s) over the average $2.0 \pm 1.4 \mathrm{~m}$ length of the investigated cavities.

During the bloom at Moses Rock (Fig. 4B), we detected no significant differences for either chl a or pheopigments along the transect (ANOVA, log-normalized data: $F_{3,38}=1.54, \mathrm{p}=0.22 ;$ and $F_{3,38}=2.06, \mathrm{p}=012$; respectively). Oxygen did, however, show significant differences between transect sections (ANOVA, lognormalized data: $F_{3,38}=6.34, \mathrm{p}<0.01$ ), notably between $\mathrm{BBL}$ and the leeward exit of the tunnel cavity (Scheffe's $p<0.01$ ), but not between BBL and the cavity itself (Scheffé's $p=0.10$ ). The average net current in this relatively open tunnel cavity $\left(1.04 \pm 0.78 \mathrm{~cm} \mathrm{~s}^{-1}\right.$, Fig. 4 B) was $36.8 \%$ of the average speed in the BBL

$A$ closer examination of the normal summer distributıons revealed marked differences in BBL chl a between sampling sites and times (Fig. 5A to D). Lowest concentrations were found at the southern sites of Ras Abu Galum and Hibiq, and highest values in Eilat at the northern tip of the Gulf of Aqaba. Nighttıme concentrations were signuficantly lower than daytime concentrations (ANOVA, log-normalized data: $F_{2,45}=21.31$, $p<0.0001$ ). The apparent differences in BBL chl a relating to 'coelobite cover' turned out to be effectively 'site' effects: this is because low coelobite cover was restricted to Hibiq, and because at the same time Hibiq 

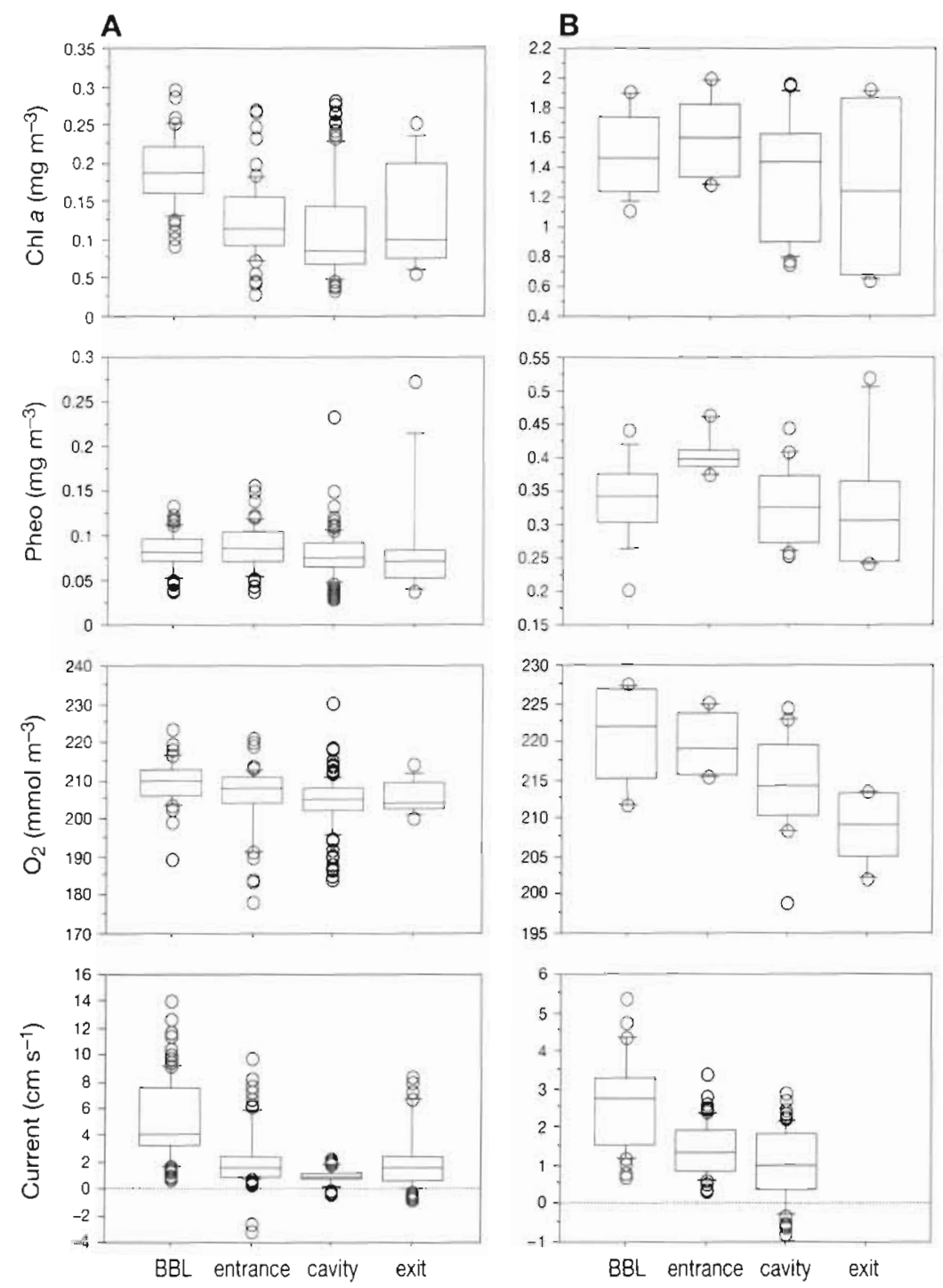

Fig. 4. Distributions (top to bottom panels) of chl $a_{1}$ pheopigments, oxygen and currents between the the bottom boundary layer (BBL), cavity entrance, cavity and cavity exits of 20 transects carried out under (A) normal summer and 2 transects carried out under (B) bloom conditions ( $\left.>0.3 \mathrm{mg} \mathrm{chl} \mathrm{a} \mathrm{m}^{-3}\right)$. Boxes encompass $50 \%$ of the data between the 25 th and 75 th percentile, center lines display the medians. The upper and lower horizontal lines delimit the 10 th and 90th percentiles, outliers are shown as open circles

coincided with the lowest chl a concentrations in BBL (Table 1). Cavity connectivity (i.e. whether the cavities were closed, semi-closed or open) did not affect BBL chl a levels (ANOVA, log-normalized data: $F_{2,45}=1.19$, $\mathrm{p}=0.31$; Fig. $5 \mathrm{C})$.

Chl a consumption in the cavities (Fig. 5E to H) appeared to be non-linearly related to chl a availability in BBL at the different sites: the effectiveness of removal increased from $18 \%$ at the low-chlorophyll site Hibiq to $62 \%$ in Ras Burka with moderate chl a levels. At higher chlorophyll levels, however, this trend reversed: in Moses Rock, Eilat, removal was effectively zero, even though this cavity was virtually carpeted with filter feeders (Table 1). Two-way ANOVA showed that connectivity and coelobite cover significantly affected chl a removal, as did the interaction term of the 2 factors (ANOVA, arcsine-transformed data: $\left.F_{1,105}=6.71, \mathrm{p}<0.05\right)$ : strongest depletions $(>60 \%)$ occurred where both coelobite cover was high and water exchange reduced. We found no significant temporal differences in chl a retention efficiency (ANOVA, arcsinetransformed data: $F_{2.45}=2.85, p=0.06$; Fig. 5F).

Oxygen concentrations in the BBL (Fig. 5I to L) varied significantly between sites and daytime hours, but also upstream of cavities of differing connectivity and coelobite cover. Diel changes of $\sim 8 \mathrm{mmol} \mathrm{m}^{-3}$ (ANOVA, logtransformed data: $F_{2,32}=6.35, \mathrm{p}<0.01$; Fig. $5 \mathrm{~J}$ ) due to light-dependent variations in the ratio between production and respiration of the reef community explain much of the variability between sites and cavity types. Thus, we find that measurements carried out in Ras Burka and closed cavities (low connectivity) are biassed towards daytime, while tunnel cavities with moderate coelobite cover hold a higher-thanaverage number of nighttime observations (Table 1). Yet, in spite of the higher BBL levels, oxygen consumption in the cavities (Fig. 5M to P) was significantly higher in sack-type (low connectivity) than in tunnel (medium and high connectivity) cavities (ANOVA, arcsine-transformed data: $F_{1,99}=44.14$, $\mathrm{p}<0.0001$; Fig. 5P), underlining the importance of water exchange on the observed depletions. Suspension feeder cover, by contrast, seemed to have little effect on the magnitude of depletion when comparing cavities with high and moderate cover (Scheffé's $\mathrm{p}=$ 0.82 ). The interaction, however, between connectivity and coelobite cover was significant (2-way ANOVA, arcsine-normalized data: $F_{1,99}=12.29, \mathrm{p}<0.001 \mathrm{j}$. Net oxygen production (negative values in Fig. $5 \mathrm{M}$ to $\mathrm{P}$ ) in cavities was encountered on 2 occasions (Table 1).

Multiple linear regression analysis (normal summer conditions) confirmed that the magnitude of chl a depletions depended on the flow of water through the 

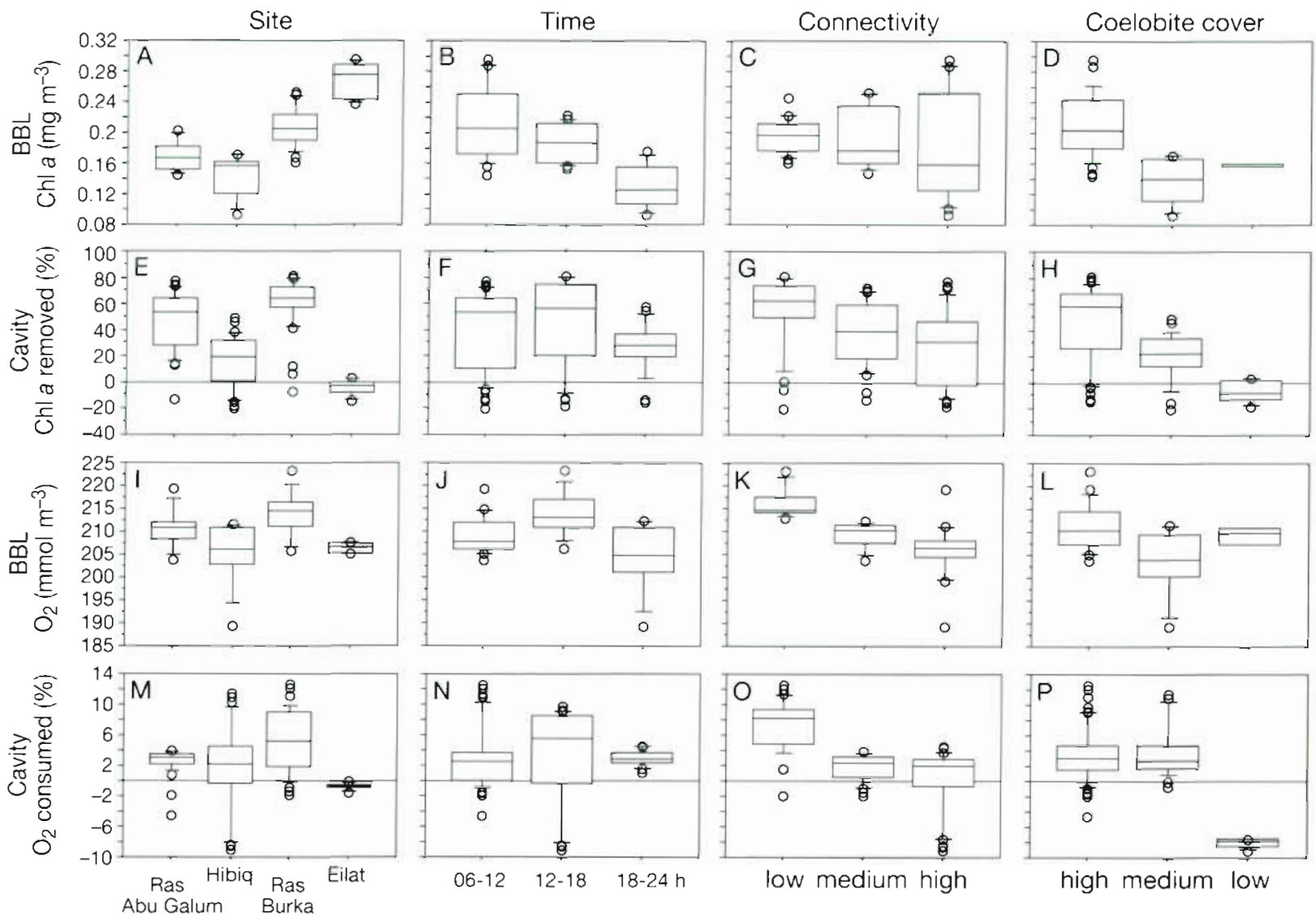

low medium high

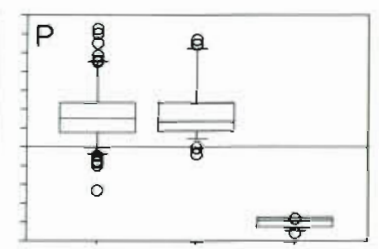

high medium low

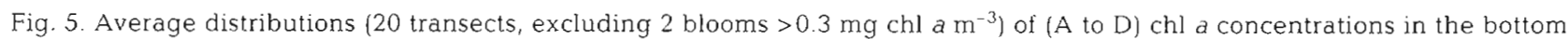
boundary layer (BBL), ( $E$ to $H$ ) chl a depletions in cavities, (I to L) oxygen concentrations in the BBL, and ( $M$ to $P$ ) oxygen consumption in the cavities, as a function of sampling sites, sampling time (hours), degree of connectivity of cavity with BBL (low: sack-shaped, medium: obstructed tunnel, high: open tunnel cavity), and coelobite suspension feeder cover (high: $>30 \%$, medium: 10 to $30 \%$, low: $<10 \%$ suspension feeder cover). See Fig. 4 for explanation of box plots

cavities, as well as on the amount of chl a present in BBL, according to the equation

$\% \Delta c=-13.9 v_{c}+375.6 c_{B B L}$

Multiple adjusted $\mathrm{R}^{2}=0.91, F_{2,9}=53.14, \mathrm{p}<0.0001$

where $\% \Delta c$ is the relative concentration difference of chl a between BBL and cavity (in \% of $\mathrm{C}_{\mathrm{BBL}}$ ), $v_{\mathrm{c}}$ is the average current speed ( $\mathrm{cm} \mathrm{s}^{-1}$ ) in the cavity and $C_{B B L}$ is the chl a concentration in BBL (Table 2).

When applied to the entire data set (normal and bloom conditions), multiple linear regression yielded no fit at all $\left(\mathrm{R}^{2}=0.26, F_{2,9}=3.24, \mathrm{p}=0.08\right)$.

Pheopigments were positively correlated with chl $a$ under bloom conditions (Fig. 6B). Under normal summer conditions, however, pheopigment concentrations remained virtually constant while chl a levels progressively declined from BBL to cavities (Fig. 6A), indicating selective removal of chl $a$ in the cavities.

Fluorescent dye experiments revealed rapid flushing of cavity waters in the order of only minutes (Fig. 7). Fluo- rescein injected into the upstream entrance of Moses Rock took 3:20 min (corresponding to a travel speed of $2.0 \mathrm{~cm} \mathrm{~s}^{-1}$ ) to reach the leeward end of the $4 \mathrm{~m}$ tunnel cavity and was diluted to threshold concentrations in 10 min (Fig. 7 A). Ambient speed in the BBL at that time was $8.2 \mathrm{~cm} \mathrm{~s}^{-1}$. In 36 flushing experiments carried out to date, $90 \%$ of the fluorescein injected into the cavity was washed out in about $3 \mathrm{~min}$ and $99 \%$ in about $8 \mathrm{~min}$ (Fig. 7B). In Ras Burka, where we found the highest chl $a$ depletions ( $>60 \%$, Fig. 5E), the dye travelled through the $2.5 \mathrm{~m}$ diameter patch reef at $0.8 \mathrm{~cm} \mathrm{~s}^{-1}$ after which it was found seeping out of several downstream openings before being carried away by the BBL current at $2.9 \mathrm{~cm} \mathrm{~s}^{-1}$.

\section{DISCUSSION}

This study is the first account, to our knowledge, of significant depletions of chl a between BBL and coral reef cavities. 

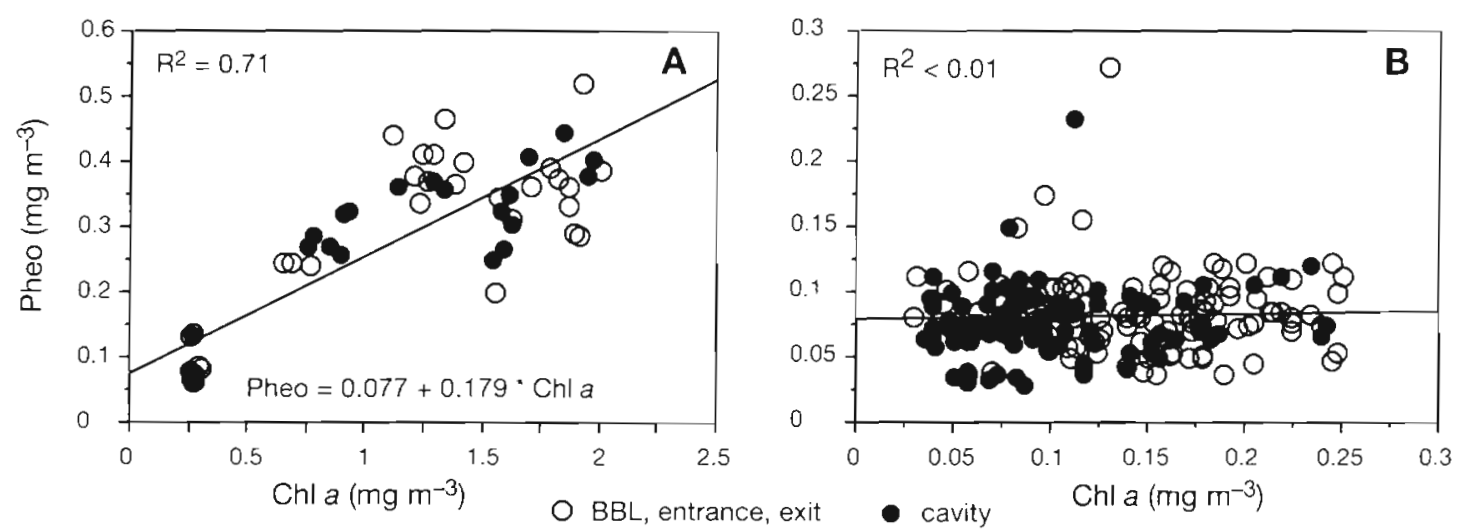

Fig. 6. Pheopigment versus chl a concentrations for (A) bloom (>0.3 $\mathrm{mg} \mathrm{chl} \mathrm{a} \mathrm{m}^{-3}$ ) and (B) oligotrophic summer conditions in the Gulf of Aqaba. (O) Bottom boundary layer (BBL) waters, cavity entrances and exits; ( $)$ cavity values

Contrary to the gradients described from the large Mediterranean caverns, which feature long water residence times (days, Fichez 1991) and successive impoverishment of the fauna towards their inner reaches (Riedl 1966, Gili et al. 1986), the much smaller-scale gradients we measured in coral reef cavities during this study were accompanied by very short water residence times (minutes) and flourishing coelobite communities. In fact, almost all cavities inspected at our sites and elsewhere in the Gulf of Aqaba (Wunsch unpubl.) harboured dense cryptic communities. Only in Hibiq, for one reason or another, we found less developed assemblages. This shows that food supply to the cavity system is sufficient to nourish a generally rich cryptic suspension feeding benthos, in spite of the general paucity of suspended organic matter in oligotrophic reef waters (Sargent \& Austin 1949, Odum \& Odum 1955).

In order to produce a conservative estimate for phytoplankton removal by the coelobite community, we modelled the water flow $\left(\mathrm{m} \mathrm{s}^{-1}\right)$ and $\mathrm{chl} a\left(\mathrm{mg} \mathrm{m}^{-3}\right)$ changes across an idealized section of cavernous forereef slope, under normal summer conditions $<0.3 \mathrm{mg}$ chl $\mathrm{a} \mathrm{m}^{-3}$ ), according to the equation

$$
F=\hat{\mathrm{v}}_{\mathrm{c}} \times \Delta \mathrm{c} \times \Delta \mathrm{L}^{-1} \times \mathrm{p}_{\mathrm{c}} \times \mathrm{k}
$$

$F$ is the amount of phytoplankton carbon retained per unit volume of cavernous reef $\left(\mathrm{g} \mathrm{C} \mathrm{m}^{-3} \mathrm{~d}^{-1}\right.$ or $\mathrm{g} \mathrm{C} \mathrm{m}^{-2}$ $\mathrm{d}^{-1}$ normalized to the upper $1 \mathrm{~m}$ framework), $\dot{\mathrm{v}}_{\mathrm{c}}$ is the median net flow through cavities $\left(8.9 \times 10^{-3} \mathrm{~m} \mathrm{~s}^{-1}\right.$, Fig. $4 \mathrm{~A}), \Delta \mathrm{c}$ is the chl a concentration difference between BBL and cavity $\left(1.0 \times 10^{-4} \mathrm{~g} \mathrm{chl} \mathrm{a} \mathrm{m}^{-3}\right.$. Fig. $\left.4 \mathrm{~A}\right)$, $\Delta \mathrm{L}$ is the median cavity length $(2 \mathrm{~m}$, Table 1$), \mathrm{p}_{\mathrm{c}}$ is a conservative estimate for the fraction of cavities per unit volume of reef $(0.3$, Gischler \& Ginsburg 1996, Wunsch \& Richter unpubl.), and $\mathrm{k}$ is a constant $(5.184 \times$ $\left.\left.10^{6} \mathrm{~g} \mathrm{C} \mathrm{g} \mathrm{chl} \mathrm{a}\right]^{-1} \mathrm{~s} \mathrm{~d}^{-1}\right)$, assuming a carbon:chl a ratio of 60 for phytoplankton in oligotrophic waters near the reef (Legendre et al. 1988). This model yields a substantial retention of $0.70 \mathrm{~g} \mathrm{C} \mathrm{m}^{-2} \mathrm{~d}^{-1}$, roughly 1 order of magnitude higher than previous estimates of pico-
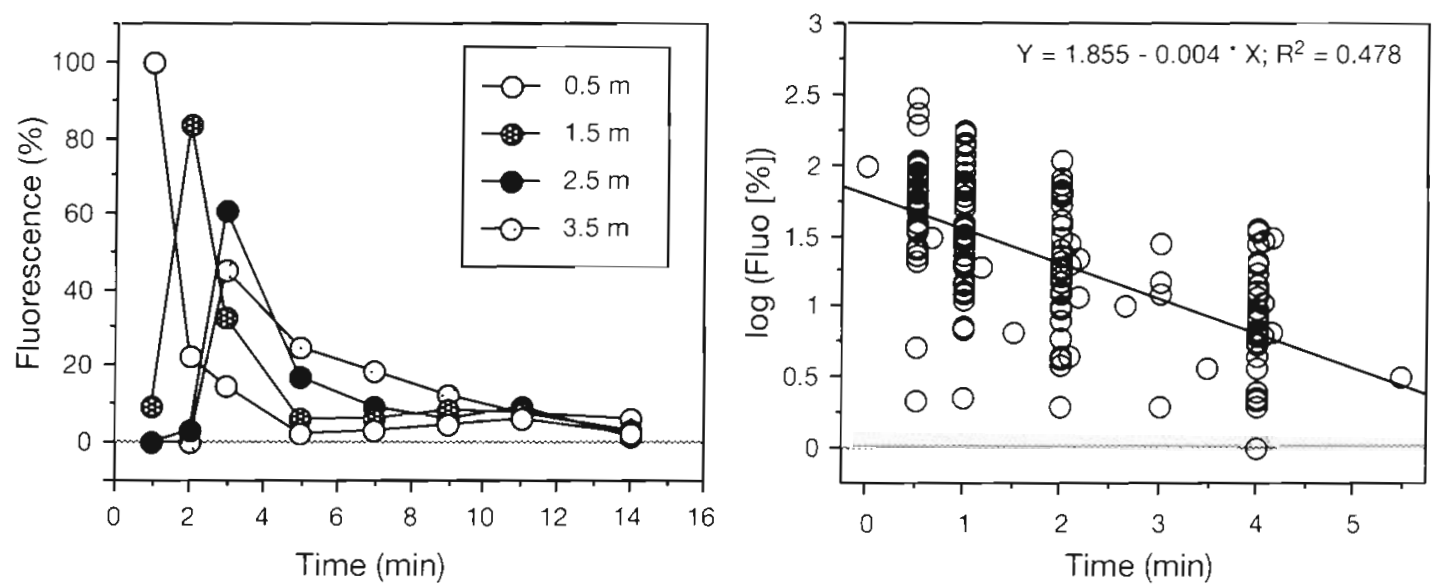

Fig. 7. Fluorescent dye dilution experiments. (A) Propagation of the dye patch from the upstream to the downstream end of a $4 \mathrm{~m}$ tunnel cavity pinnacle in Moses Rock, Eilat, showing the exponential decay of the fluorescence signal over time at the 4 sampling points $(0.5$ to $3.5 \mathrm{~m}$ from upstream entrance). (B) Exponential decay of the dye fluorescence signal in coral reef cavities of the Gulf of Aqaba ( 36 experiments) 
plankton retention in waters flowing over the reef flat (Ayukai 1995). Our average figure is thus in the range of maximum rates reported so far for epibenthic reef communities (Fabricius et al. 1998, Yahel et al. 1998), highlighting the importance of cavity-dwelling suspension feeders in channeling suspended food from the BBL into the coral reef.

In order to validate our model, we carried out a separate analysis for phytoplankton retention in Moses Rock, according to the equation

$$
F_{\mathrm{c}}=\mathrm{v}_{\mathrm{e}} \times \mathrm{A}_{\mathrm{e}} \times \Delta \mathrm{c} \times \mathrm{A}_{\mathrm{c}}{ }^{-1} \times \mathrm{k}
$$

where $F_{c}$ is the amount of phytoplankton carbon retained per square meter of cavity wall $\left(\mathrm{g} \mathrm{C} \mathrm{m}^{-2} \mathrm{~d}^{-1}\right), \mathrm{v}_{e}$ $\times A_{e}$ is the volume flux of water across the cavity entrance $\left(0.01 \mathrm{~m} \mathrm{~s}^{-1} \times 0.44 \mathrm{~m}^{2}\right), \Delta \mathrm{c}$ is the chl a concentration difference between $\mathrm{BBL}$ and cavity $\left(6.58 \times 10^{-4} \mathrm{~g}\right.$ chl $\left.a \mathrm{~m}^{-3}\right), \mathrm{A}_{\mathrm{c}}$ is the surface area of the tunnel cavity, approximated by a cylinder $\left(9.4 \mathrm{~m}^{2}\right)$, and $\mathrm{k}$ is the above constant. This mass-balance model yields an uptake of $1.60 \mathrm{~g} \mathrm{C} \mathrm{d}^{-1}$ per square meter cavity wall. Assuming a conservative factor of 2 between cavity area and that of the reef surface (Buss \& Jackson 1979, Logan et al. 1984), this translates into an uptake of $0.80 \mathrm{~g} \mathrm{C} \mathrm{d}^{-1}$ on a square meter reef basis, reasonably close to the previous figure for the cavity system.

The models support the at first counterintuitive notion of high pelagic-benthic coupling in oligotrophic waters, where a rich albeit hidden suspension feeding benthos thrives on a dilute suspension of particulate food. They show how short residence times (Dill 1977. the present study) and high filter efficiencies (Reiswig 1971, Pile et al. 1996, Pile 1997) combine to give rise to community retention rates, which are comparable in magnitude to those measured over dense aggregations of suspension feeders in other marine and freshwater habitats (Jørgensen 1990, Petersen \& Riisgård 1992, Riisgård et al. 1996, Pile et al. 1997, Gili \& Coma 1998).

The short residence time of water over the narrow shelf (hours) and the short phytoplankton doubling times $\left(0.4\right.$ to $3 \mathrm{~d}^{-1}$; Ayukai 1992, Ferrier-Pagès \& Gattuso 1998 ) show that the phytoplankton is mainly an allochthonous source of food to the coelobite suspension feeders. It enters the cavernous framework through flow speed differences in the BBL. The resulting pressure difference between the intake openings and the elevated output openings creates a secondary flow through the cavity system, much like the wind-induced ventilation of termite mounds (Weir 1973) or the current-induced flow through living sponges (Vogel 1974, 1977). It should be noted that the direction of flow is not so important as the speed difference between intake and exhaust. The increase in the cross-sectional area between the single large cavity entrance and the numerous smaller exhaust openings results in a de- celeration of flow in the inner reaches of the cavity (Fig. 4). It is in this area of reduced flow where we found the strongest depletions (Fig. 3) and highest proportions of active suspension feeders (Wunsch \& Richter 1998, Wunsch unpubl.). By analogy, the coral reef framework may thus be seen as a giant 'sponge' (J.-M. Gili pers. comm.), where the cavities take the role of the internal channels and the coelobite suspension feeders the function of the choanocyte chambers retaining phytoplankton (the present study), bacteria (Gast et al. 1998), heterotrophic nanoflagellates (Buss \& Jackson 1981) and likely other suspended and dissolved organic matter (e.g. mucus, as suggested by Pérès \& Picard 1969). In this regard it is interesting to note that the maximum community filtration efficiencies we report in our study (86\%) approach that of filter-feeding individuals (Reiswig 1971, Pile et al. 1996).

Curiously, the pheopigment concentrations in the cavities did not increase in response to phytoplanktonderived production of feces (Currie 1962), nor did they decrease as a result of unselective grazing of both chl a and pheopigment-rich particles, as optimum foraging theory would predict for active suspension feeders (Gili \& Coma 1998). Instead, pheopigment concentrations remained surprisingly constant, in contrast to the strong depletions of chl $a$. This points to an efficient selection mechanism between high- and low-value food (chl a and pheopigments), as was shown to occur even in ancestral organisms such as sponges (Kilian 1980, Wolfrath \& Barthel 1989). A similar decoupling of chl $a$ and pheopigments was described for community grazing by a fouling community on harbour pilings in Eilat (Yahel et al. 1998). In both instances, grazed chl a was probably broken down into non-fluorescent units or compacted into larger fecal units which escaped detection. Whatever the cause, the differential retention of the 2 pigments discredits mucus scavenging, wall adsorption or other non-biological mechanisms in explaining the notorious phytoplankton depletions near coral reefs (Glynn 1973, Legendre et al. 1988, Ayukai 1995, Yahel et al. 1998).

Zooplankton which may abound locally near the reef (Emery 1968, Hamner \& Carleton 1979) did not occur in conspicuous aggregations in the cavities in the course of our study, and the limited data on reefassociated plankton available for the Gulf of Aqaba suggest that zooplankton would have an insignificant effect on phytoplankton pigment concentrations near the reef (Yahel et al. 1998).

Although flow through the cavernous framework is largely limited to macroscopic cavities, crevices and cracks (Andrews \& Pickard 1990, Wolanski 1994), flow also occurs through the porous carbonate matrix, albeit at 1 to several orders of magnitude lower pore-water velocities (Buddemeier 1981, Roberts et al. 1988, Wo- 
lanski 1994), and water residence times in the order of days rather than minutes (Tribble et al. 1992). Seepage from the framework is unlikely to affect the large chl a concentration differences we measured between BBL and cavities, but it may well affect the small differences we detected in the oxygen concentrations: 1 to 2 orders of magnitude lower oxygen concentrations (Sansone et al. 1988) and 3 to 4 orders of magnitude slower porewater flows (Tribble et al. 1992), may explain a few percent lower oxygen values in the cavity system. The effect of seepage may thus outweigh the effect due to the respiratory demand of the sessile coelobite community, because the respiratory cost of capture in suspension feeders is very low (Gili \& Coma 1998).

Various interacting antagonistic physical and biological processes (e.g. wave action, advection, photosynthesis by sciaphilic algae, respiration by vagrant organisms, remineralization of their feces, etc.) working on different spatial and temporal scales, as well as high background levels and large diurnal variations in the $\mathrm{BBL}$ render the interpretation of the oxygen data difficult. Yet, in spite of these limitations, we saw that, with the exception of occasional oxygen peaks in the sun-lit cavity entrances, heterotrophic processes dominate over autotrophic processes in this light-protected habitat.

The animal-dominated coelobite community led Pérès \& Picard (1969) to postulate that large amounts of the coral reef primary production were 'wasted' in the 'mesh-like' framework. Our study shows that in addition to reef-derived material which is deposited and remineralized in the cavities, a significant input occurs in terms of phytoplankton and likely other suspended and dissolved organic matter. This largely allochthonous material is trapped by the cryptic suspension feeders, effectively providing new nutrients and energy to the coral reef ecosystem.

The magnitude of this flux on the one hand, and the low densities (22 $\mathrm{m}^{-2}$, Yahel et al. 1998) and small size (cm) of the dominant epi-reefal phytoplankton grazers on the other (Maier 1998, Yahel et al. 1998), as well as reported phytoplankton depletions over denuded reef sections (B. Lazar pers. comm.), give us reason to assume that coelobite suspension feeders may account for much if not most of the ultraphytoplankton depletions observed near coral reefs in the Red Sea (Yahel et al. 1998) and possibly also other parts of the world (Glynn 1973, Ayukai 1995). A comparative investigation of epi-reefal and coelobite community grazing is therefore highly needed.

Acknowledgements. This research is part of Project B of the Red Sea Program for Marine Sciences (RSP), funded by the German Federal Ministry of Education and Research (BMBF, grant no. 03F0151A). Thanks are due to our RSP colleagues, in particular to G. Yahel, R. Yahel and A. Genin for logistic assistance and useful suggestions, and to I. Kötter and E. Saadalla for their help in the field. G. Hempel, K. Fabricius and 5 anonymous reviewers provided valuable critical revisions of the manuscript. We thank the competent Egyptian and Israelj. Authorities for their permission to carry out this investigation.

\section{LITERATURE CITED}

Andrews JC, Pickard GL (1990) The physical oceanography of coral-reef systems. In: Dubinsky $Z$ (ed) Coral reefs. Elsevier, Amsterdam, $p$ 11-48

Ayukai T (1992) Picoplankton dynamics in Davies Reef lagoon, the Great Barrier Reef, Australia. J Plankton Res 14: 1593-1606

Ayukai $T$ (1995) Retention of phytoplankton and planktonic microbes on coral reefs within the Great Barrier Reef, Australia. Coral Reefs 14:141-147

Barnes DJ, Lazar B (1993) Metabolic performance of a shallow patch reef near Eilat on the Red Sea. J Exp Mar Biol Ecol 174:1-13

Buddemeier RW (1981) The geohydrology of Enewetak Atoll islands and reefs. Proc 4th Int Coral Reef Symp, Manila 1: $339-345$

Buss LW (1979) Bryozoan overgrowth interactions - the interdependence of competition for space and food. Nature 281:475-477

Buss LW, Jackson JBC (1979) Competetive networks: nontransitive competitive relationships in cryptic coral reef environments. Am Nat 11.3:224-234

Buss LW, Jackson JBC (1981) Planktonic food availability and suspension-feeder abundance: evidence of in situ depletion. J Exp Mar Biol Ecol 49:151-161

Currie RI (1962) Pigments in zooplankton faeces. Nature 193: 956-957

Dill RF (1977) The blue holes-geologically significant submerged holes and caves of British Honduras and Andros, Bahama Islands. Proc 3rd Int Coral Reef Symp, Miami, FL, $2: 237-242$

Ducklow HW (1990) The biomass, production and fate of bacteria in coral reefs. In: Dubinsky Z (ed) Coral reefs. Elsevier Science Publishing, New York, p 265-289

Emery AR (1968) Preliminary observations on coral reef plankton. Limnol Oceanogr 13:293-303

Fabricius KE, Yahel G, Genin A (1998) In situ depletion of phytoplankton by an azooxanthellate soft coral. Limnol Oceanogr 43:354-356

Ferrier-Pagès C, Gattuso JP (1998) Biomass, production and grazing rates of pico- and nanoplankton in coral reef waters (Miyako Island, Japan). Microb Ecol 35:46-57

Fichez R (1991) Suspended particulate organic matter in a Mediterranean submarine cave. Mar Biol 108:167-174

Garrett P, Smith DL, Wilson AD, Patriquin D (1971) Physiography, ecology and sediments of two Bermuda patch reefs. J Geol 79:647-668

Gast GJ, Wiegmann S, Wieringa E, van Duyl FC, Bak RPM (1998) Bacteria in coral reef water types: removal of cells, stimulation of growth and mineralization. Mar Ecol Prog Ser 167:37-45

Genin A, Lazar B, Brenner S (1995) Vertical mixing and coral death in the Red Sea following the eruption of Mount Pinatubo. Nature 377:507-510

Gili JM, Coma R (1998) Benthic suspension feeders: their paramount role in littoral marine food webs. Trends Ecol Evol 13:297-337

Gili JM, Riera T, Zabala M (1986) Physical and biological gradients in a submarine cave on the Western Mediterranean coast (north-east Spain). Mar Biol 90:291-297

Ginsburg RN (1983) Geological and biological roles of cavities 
in coral reefs. In: Barnes DJ (ed) Perspectives on coral reefs. Australian Institute of Marine Science, Townsville, p 148-153

Ginsburg RN, Schroeder JH (1973) Growth and submarine fossilization of algal cup reefs, Bermuda. Sedimentology 20.575-614

Gischler E, Ginsburg RN (1996) Cavity dwellers (coelobites) under coral rubble in Southern Belize barrier and atoll reefs. Bull Mar Sci 58:570-589

Glynn PW (1973) Ecology of a Caribbean coral reef, the Porites reef flat biotope. Part li. Plankton community with evidence for depletion. Mar Biol 22:1-22

Grasshoff K, Ehrhardt M, Kremling K (1976) Methods of seawater analysis. Verlag Chemie, Weinheim

Hamner WM, Carleton JH (1979) Copepod swarms: attributes and role in coral reef ecosystems. Limnol Oceanogr 24:1-14

Hutchings PA (1974) A preliminary report on the density and distribution of invertebrates living on coral reefs. Proc 2nd Int Coral Reef Symp, Brisbane 1:285-296

Jackson JBC, Goreau TF, Hartman WD (1971) Recent brachiopod-coralline sponge communities and their paleoecological significance. Science 173:623-625

Jørgensen CB (1990) Bivalve filter feeding: hydrodynamics. bioenergetics, physiology and ecology. Olsen and Olsen Fredensborg

Kilian EF (1980) Stamm Porifera. In: Gruner HE (ed) Wirbellose Tiere. Gustav Fischer, Stuttgart, p 251-288

Kobluk DR, van Soest RWM (1989) Cavity-dwelling sponges in a southern Caribbean coral reef and their paleontological implications. Bull Mar Sci 44:1207-1235

Legendre L, Demers S, Delesalle B, Harnois C (1988) Biomass and photosynthetic activity of phototrophic picoplankton in coral reef waters (Moorea Island, French Polynesia). Mar Ecol Prog Ser 47:153-160

Lindell D, Post AF (1995) Ultraphytoplankton succession is triggered by deep winter mixing in the Gulf of Aqaba (Eilat), Red Sea. Limnol Oceanogr 40:1130-1141

Logan A, Mathers SM, Thomas MLH (1984) Sessile invertebrate coelobite communities from reefs of Bermuda: species composition and distribution. Coral Reefs 2:205-213

Maier C (1998) A field survey on the abundance and distribution of internal bioeroders in coral reefs. International Society for Reef Studies, European meeting, Perpignan (abstract)

Meesters E, Knijn R, Willemsen P, Pennartz R, Roebers G, van Soest RWM (1991) Sub-rubble communities of Curaçao and Bonaire coral reefs. Coral Reefs 10:189-197

Odum HT, Odum EP (1955) Trophic structure and productivity of a windward coral reef community on Eniwetok A.toll. Ecol Monogr 25:291-320

Parsons TR, Maita Y, Lalli CM (1984) A manual of chemical and biological methods of seawater analysis. Pergamon Press, Oxford

Pérès JM, Picard J (1969) Réflexions sur la structure trophique des édifices récifaux. Mar Biol 3:227-232

Petersen JK, Riisgård HU (1992) Filtration capacity of the ascidian Ciona intestinalis and its grazing impact in a shallow fjord. Mar Ecol Prog Ser 88:9-17

Pile A.J (1997) Finding Reiswig's missing carbon: quantification of sponge feeding using dual-beam cytometry. Proc 8th Int Coral Reef Symp, Panama 2:1403-1410

Pile AJ, Patterson MR, Witman JD (1996) In situ grazing on plankton $<10 \mu m$ by the boreal sponge Mycale lingua. Mar Ecol Prog Ser 141:95-102

Pile AJ, Patterson MR, Savarese M, Chernykh VI, Fialkov VA. (1997) Trophic effects of sponge feeding within Lake Baikal's littoral zone. 2. Sponge abundance, diet, feeding efficiency, and carbon flux. Limnol Oceanogr 42:178-184
Reiss Z, Hottinger L (1984) The Gulf of Aqaba (Eilat)-ecological micropaleontology. Springer-Verlag, Berlin

Reiswig HM (1971) Particle feeding in natural populations of three marine demosponges. Biol Bull 141:568-591

Riedl R (1966) Biologie der Meereshöhlen. P Parey, Hamburg

Riisgård HU, Poulsen L, Larsen PS (1996) Phytoplankton reduction in near-bottom water caused by filter-feeding Nereis diversicolor-implications for worm growth and grazing impact. Mar Ecol Prog Ser 141:47-54

Roberts HH, Lugo A, Carter B, Simms M (1988) Across-reef flux and shallow subsurface hydrology in modern coral reefs. Proc 6th Int Coral Reef Symp, Townsville 2:509-515

Roman MR, Furnas MJ, Mullin MM (1990) Zooplankton abundance and grazing at Davies Reef, Great Barrier Reef, Australia. Mar Biol 105:73-82

Sachs L (1992) Angewandte Statistik-Anwendung statistischer Methoden. Springer-Verlag, Berlin

Sansone FJ, Tribble GW, Buddemeier RW, Andrews CC (1988) Time and space scales of anaerobic diagenesis within a coral reef framework. Proc 6th Int Coral Reef Symp, Townsville 3:367-372

Sargent MC. Austin TS (1949) Organic productivity of an atoll. Trans Am Geophys Union 30:245-249

Shashar N, Kinane S, Jokiel PL, Patterson MR (1996) Hydromechanical boundary layers over a coral reef. J Exp Mar Biol Ecol 199:17-28

Tribble GW, Sansone FJ, Buddemeier RW, Li YH (1992) Hydraulic exchange between a coral reef and surface sea water. Geol Soc Am Bull 104:1280-1291

Turner Associates GK (1971) Fluorometry in studies of pollution and movement of fluids. GK Turner Associates, Palo Alto, CA

Vasseur P (1974) The overhangs, tunnels and dark reef galleries of Tuléar (Madagascar) and their sessile invertebrate communities. Proc 2nd Int Coral Reef Symp, Brisbane 2:143-159

Vasseur P (1977) Cryptic sessile communities in various coral formations on reef flats in the vicinity of Tulear (Madagascar). Proc 3rd Int Coral Reef Symp, Miami, FL, 1:95-100

Vogel S (1974) Current-induced flow through the sponge Halichondria. Biol Bull 147:443-456

Vogel S (1977) Current-induced flow through living sponges in nature. Proc Natl Acad Sci USA 74:2069-2071

Vogel S (1994) Life in moving fluids - the physical biology of flow. Princeton University Press, Princeton, NJ

Weir JS (1973) Air flow, evaporation and mineral accumulation in mounds of Macrotermes subhyalinus (Rambur). J Anim Ecol 42:509-520

Wilkinson CR, Vacelet J (1979) Transplantation of marine sponges to different conditions of light and current. J Exp Mar Biol Ecol 37:91-104

Winston JE (1976) Experimental culture of the estuarine ectoproct Conopeum tenuissimum from Chesapeake Bay. Biol Bull 150:318-335

Wolanski E (1994) Physical oceanographic processes of the Great Barrier Reef. CRC Press, Boca Raton

Wolfrath B, Barthel D (1989) Production of faecal pellets by the marine sponge Halichondria panicea PALLAS (1766). J Exp Mar Biol Ecol 129:81-94

Wunsch M. Richter C (1998) The CaveCam-an endoscopic underwater videosystem for the exploration of cryptic habitats. Mar Ecol Prog Ser 169:277-282

Yahel G, Post AF, Fabricius KE, Marie D, Vaujot D, Genin A (1998) Phytoplankton distribution and grazing near coral reefs. Limnol Oceanogr 43:551-563

Zankl H, Schroeder JH (1972) Interaction of genetic processes in Holocene reefs off North Eleuthera Island, Bahamas. Geol Runds 61:520-541 